Apidologie 1980, 11 (2), 173-180.

\title{
INFLUENCE OF THE NUMBER OF ATTENDANT WORKERS ON THE RESULTS OF INSTRUMENTAL INSEMINATION OF HONEYBEE QUEENS KEPT AT ROOM TEMPERATURE
}

\author{
Jerzy WOYKE and Zygmunt JASINSKI \\ Bee Division, Agricultural University, 02-766 Warszawa, \\ Nowoursynowska 166, Poland
}

\begin{abstract}
SUMMARY
Altogether 60 queens were instrumentally inseminated with $8 \mathrm{~mm}^{3}$ of semen. They were placed into small boxes kept at room temperature, with different numbers of attendant workers. Temperature inside the bee cluster was measured twice a day. Queens were killed and examined $48 \mathrm{hrs}$ after insemination.

The increase of the number of attendant workers, from 20 up to 350 , resulted in an increase of the number of spermatozoa migrating into the queen's spermatheca from 1.825 million up to 4.102 million. Thus a 2.25 times increases of the number of spermatozoa in the spermatheca was achieved by the higher number of attendants.

While 20 or 40 workers were able to raise the inside temperature only $2^{\circ} \mathrm{C}-3{ }^{\circ} \mathrm{C}$ above the outside temperature, 250 or 350 workers raised the temperature $12^{\circ} \mathrm{C}-14^{\circ} \mathrm{C}$ reaching $32.7^{\circ} \mathrm{C}$ and $34.6^{\circ} \mathrm{C}$ respectively.

Very high correlation was found to exist between the number of attendant workers, the temperature inside the small bee cluster, and the number of spermatozoa in the queen's spermatheca. Regression coefficients indicated that an increase of 100 attendant workers raised the temperature $3.5^{\circ} \mathrm{C}$ and the number of spermatozoa in spermatheca by 629 thousand.
\end{abstract}

\section{INTRODUCTION}

WOYKe (1979) showed that a significant increase of the number of spermatozoa entering the spermatheca of instrumentally inseminated queens may be achieved not after the queens are caged in a nursery colony, but when worker bees have access to them. WOYKE and JASINSKI (1979) showed that 250 workers should attend queens kept in an incubator after instrumental insemination. But many queen breeders keep 
queens, after instrumental insemination, at outdoor temperatures in different micronuclei, babynuclei, varying sizes of mating nuclei, or different boxes. The temperature inside the small bee cluster may differ significantly from that in a normal colony or in an incubator. WOYKE (1960) showed that the process of transpassing of spermatozoa from oviducts into the spermatheca lasted about $24 \mathrm{hrs}$. Thus the low temperature, as well as other unfavorable conditions interfere with that process. VESELY (1969) already found that queens kept after insemination in cages with 5 to 10 workers did not clear their oviducts from semen, while those kept in nuclei did. WOYKE and JASINSKI (1973) showed that queens kept after instrumental insemination at $34^{\circ} \mathrm{C}$ had about 1 million more spermatozoa in the spermatheca than those kept with 10 workers in a nursery colony or in an incubator at $24^{\circ} \mathrm{C}$.

Thus the question arises, what is the lowest number of workers required to attend instrumentally inseminated queens kept in small nuclei outside an incubator?

\section{MATERIALS AND METHODS}

Altogether 60 queens, 7 to 10 days old, were inseminated instrumentally with $8 \mathrm{~mm}^{3}$ of semen. Immediately after insemination all queens were placed into small boxes with workers varying in number from 20 to 350 . Queens inseminated on the same day were introduced to workers of all number combinations of attendants. Workers were treated with $\mathrm{CO}_{2}$ and were asleep at the time the queen was introduced. Boxes of $5.5 \mathrm{~cm} \times 12 \mathrm{~cm} \times 12 \mathrm{~cm}$ were supplied with a piece of comb, syrup, and bee candy as described by WOYKE and JASINSKI (1979). Boxes were left in a shelter. The temperature inside the small bee cluster was measured twice a day : at $10.30 \mathrm{a} . \mathrm{m}$. and at $18.00 \mathrm{p} . \mathrm{m}$. At the same time, the room temperature was measured. Queens were killed two days after insemination. The spermatheca was dissected and the number of spermatozoa in it was counted as described several times. Fisher's analysis of variance was applied and new multiple range test was used, to find statistically significant differences.

\section{RESULTS}

\section{Number of spermatozoa in spermatheca}

Table 1 shows that queens kept after insemination with 20 workers had an average of only 1.825 million spermatozoa in the spermatheca. An increase in the number of attendants to 40 , increased only insignificantly the number of spermatozoa found in the spermatheca. But when the queens were kept with 80 workers a statistically significant increase in the number of sperms migrating into the spermatheca was found. A further significant increase occured, when inseminated queens were kept with 150 workers. Queens kept with that number of attendants, had an average of 1.330 million more sperms in the spermatheca, than those kept with 20 workers. The highest average number of 4.102 million spermatozoa was found in spermatheca of queens kept with 350 attendant workers. These queens had an average of 2.277 
TABL. 1. - Number of spermatozoa in spermatheca of queens inseminated with $8 \mathrm{~mm}^{3}$ of semen and kept afterwards at a room temperature with a different number of attendant workers (per 10 queens in every group).

\begin{tabular}{c|c|c}
\hline \multirow{2}{*}{$\begin{array}{c}\text { No. of attendant } \\
\text { workers }\end{array}$} & \multicolumn{2}{|c}{ Million spermatozoa } \\
\cline { 2 - 3 } & Range & Mean \pm stand. error \\
\hline 20 & $1.325-2.595$ & $1.825 \pm 0.122 \mathrm{a}^{*}$ \\
40 & $1.590-2.880$ & $2.177 \pm 0.154 \mathrm{a}$ \\
80 & $2.074-3.465$ & $2.680 \pm 0.141 \mathrm{~b}$ \\
150 & $2.240-3.839$ & $3.155 \pm 0.150 \mathrm{c}$ \\
250 & $2.325-4.197$ & $3.426 \pm 0.185 \mathrm{c}$ \\
350 & $3.537-4.670$ & $4.102 \pm 0.116 \mathrm{~d}$ \\
\hline
\end{tabular}

* Different letters indicate that the differences between means are statistically significant $\mathrm{P}<0.05$.

million more sperms in the spermatheca than those kept with only 20 workers. This means that the number of spermatozoa migrating into the spermatheca of the queens kept with 350 workers was 2.25 times higher than that of queens kept with only 20 workers.

\section{Temperature inside and outside of the bee cluster}

Table 2 shows that the outside temperature, at which queens were kept with attendant workers, varied from $18^{\circ} \mathrm{C}$ up to $25^{\circ} \mathrm{C}$. The average room temperature was $20.2^{\circ} \mathrm{C}$. A group of 20 workers was able to raise the temperature in the cluster only $2.8^{\circ} \mathrm{C}$ above the outside temperature, and 40 workers raised it by $3.9^{\circ} \mathrm{C}$ above the outside temperature. However, 80 workers already raised the temperature by $8{ }^{\circ} \mathrm{C}$ above the outside temperature. Higher numbers of workers increased the temperature in the cluster even further. The average temperature inside a cluster of 250 workers was $33{ }^{\circ} \mathrm{C}$ and that was $12.8^{\circ} \mathrm{C}$ higher than the outside temperature, and only $1.8^{\circ} \mathrm{C}$ lower from that found in the brood nest of a bee colony. A cluster of 350 workers raised the average temperature by $14.5^{\circ} \mathrm{C}$ up to $34.7^{\circ} \mathrm{C}$. Table 2 shows that the temperature inside that cluster several times reached $35^{\circ} \mathrm{C}$ and even $35.5^{\circ} \mathrm{C}$.

\section{Correlation and regression coefficients}

Although the relations between the three variables are not exactly strict ones, Table 3 shows that very close correlations $(r=0.94-0.99)$ were found to exist between the number of attendant workers, the temperature inside the small bee cluster in the box, and the number of spermatozoa entering the queen's spermatheca.

Calculated regression coefficients are valid for the investigated circumstances only, when the number of attendant workers range from 20 to 350 and the room 


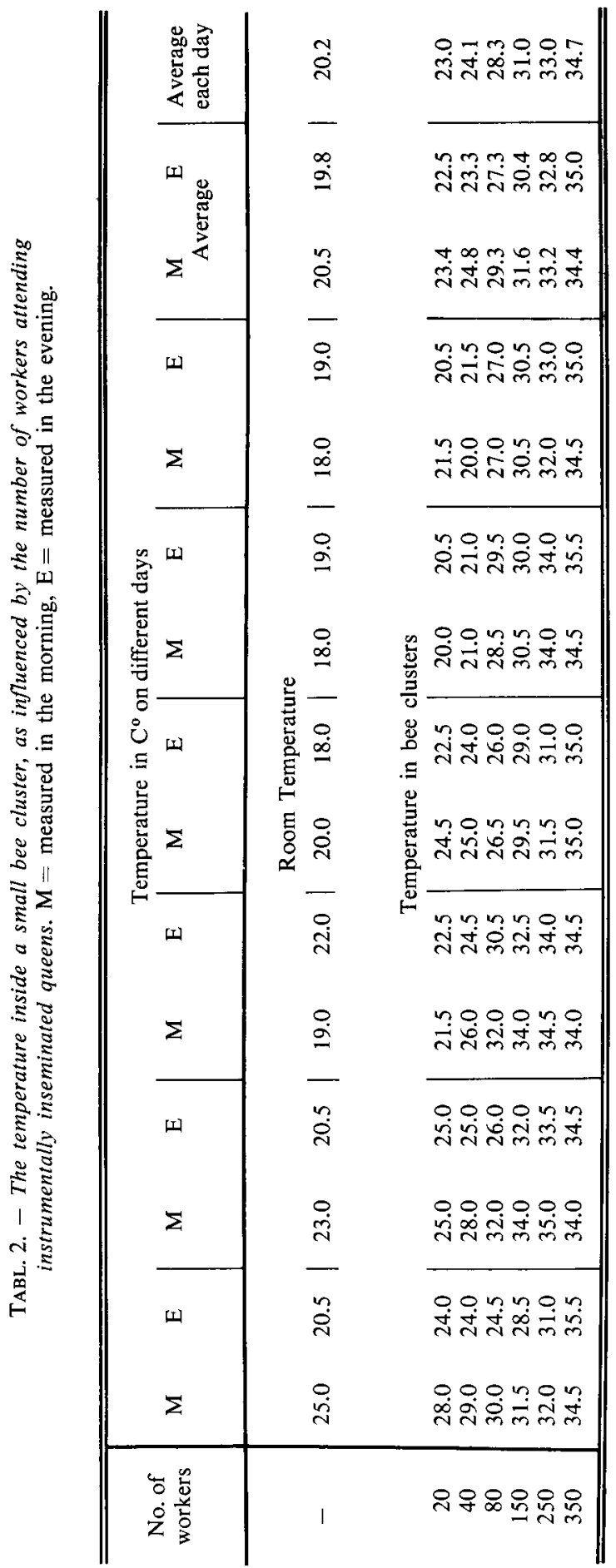


temperature from $18-25^{\circ} \mathrm{C}$. Regression coefficients presented in Table 3 indicate that an increase of 100 attendant workers raised the temperature in the small bee cluster by $3.5^{\circ} \mathrm{C}$ and the number of spermatozoa entering the queen's spermatheca by 629 thousand. An increase of $1^{\circ} \mathrm{C}$ of the temperature inside the bee cluster resulted in 170 thousand more spermatozoa entering the spermatheca of the queen.

\begin{tabular}{|c|c|c|}
\hline $\begin{array}{l}\text { Coefficients } \\
\text { between } \\
\text { variables }\end{array}$ & $\begin{array}{c}\text { Correlation } \\
\text { coefficient } \\
\mathbf{r}\end{array}$ & $\begin{array}{c}\text { Regression } \\
\text { coefficient } \\
b\end{array}$ \\
\hline $\begin{array}{l}\text { No. of workers } \\
\text { and temperature }\end{array}$ & 0.94 & $0.035^{\circ} \mathrm{C}$ \\
\hline $\begin{array}{l}\text { No. of workers } \\
\text { and No. of spermatozoa } \\
\text { in spermatheca }\end{array}$ & 0.97 & 6290 sperms \\
\hline $\begin{array}{l}\text { Degree of temperature } \\
\text { and No. of spermatozoa } \\
\text { in spermatheca }\end{array}$ & 0.99 & 170323 sperms \\
\hline
\end{tabular}

\section{DISCUSSION AND CONCLUSION}

The number of spermatozoa in the spermatheca of queens kept in an incubator and attended by different number of workers has already been investigated (WOYKE and JASINSKI 1979). While queens kept in an incubator and attented by 40, 80, 160, and 250 workers had $3.1,3.4,4.4$, and 4.5 million spermatozoa in the spermatheca respectively, those kept at room temperature with $40,80,150$, and 250 attendant workers had only $2.2,2.7,3.2$, and 3.4 million spermatozoa in the spermatheca. As was already pointed out (WOYKE and JASINSKI 1973), not exclusively the number of attendant workers influenced the number of spermatozoa entering the queen's spermatheca, but also the temperature. About 150 or 250 workers must attend inseminated queens kept at room temperature, to get similar results to those of queens kept in an incubator and attented by 40 or 80 workers respectively. WOYKE (1964) showed that naturally mated queens, which had less than 3.5 million spermatozoa in the spermatheca after the first mating flight, flew out again and mated for a second time. Thus, 3.5 million spermatozoa is the lowest number which should be present in the spermatheca of instrumentally inseminated queens. This number of spermatozoa was found in spermatheca of queens attended by 250 workers. The highest number of 4.1 million spermatozoa was present in the spermatheca of queens attented by 350 workers. Here the temperature raised several times to $35^{\circ} \mathrm{C}$ and $35.5^{\circ} \mathrm{C}$, but it 
never reached a temperature of $37.5^{\circ} \mathrm{C}$, as determined by MACKENSEN (1969) to be detrimental. Nevertheless, a temperature over $35^{\circ} \mathrm{C}$ is not desired. Therefore, if inseminated queens are to be kept at room temperature, it is recommended to place them for two days into boxes with 300-350 attendant workers. Releasing instrumentally inseminated queens into larger boxes or mating nuclei with a higher number of workers would probably increase only slightly the number of spermatozoa migrating into the spermatheca.

Received for publication in February 1980.

\author{
RÉSUMÉ \\ INFLUENCE DU NOMBRE DOUVRIÈRES ACCOMPAGNATRICES \\ SUR LES RÉSULTATS DE L'INSÉMINATION ARTIFICIELLE \\ DES REINES D'ABEILLES CONSERVÉES A TEMPÉRATURE DE LA PIÈCE
}

WOYKe (1976) a montré que le nombre de spermatozoïdes pénétrant dans la spermathèque des reines inséminées artificiellement augmentait de façon significative lorsque les ouvrières avaient libre accès aux reines. WOYKE et JASINSKI (1979) ont trouvé qu'il fallait 250 ouvrières accompagnatrices pour des reines inséminées et conservées en étuve à $34^{\circ} \mathrm{C}$. Mais de nombreux éleveurs de reines conservent les reines dans des nuclei de fécondation à la température extéricure. Combien faut-il alors d'ouvrières accompagnatrices pour des reines conservées hors d'étuve?

\title{
MATERIELS ET MÉTHODES
}

On a inséminé 60 reines avec $8 \mathrm{~mm}^{3}$ de sperme, puis on les a introduites dans des cagettes de $5,5 \times 12 \times 12 \mathrm{~cm}$, contenant chacune un nombre différent d'ouvrières, conservées sous abri. On a tué les reines 2 jours plus tard et dẻnombré les spermatozoïdes présents dans leur spermathèque.

\section{RÉSULTATS}

Les reines conservées avec 20 ouvrières après insémination artificielle avaient environ en moyenne 1,825 million de spermatozoïdes dans leur spermathéque. Une augmentation du nombre d'ouvrières a résulté en un nombre accru de spermatozoïdes dans la spermathèque des reines. Le nombre moyen le plus élevé (4,102 millions de spermatozoïdes) a été trouvé dans la spermathèque des reines conservées avec 350 ouvrières accompagnatrices. Ces reines possédaient 2,277 millions de spermatozoïdes de plus que celles conservées avec 20 ouvrières, ce qui signifie que 2,25 fois plus de spermatozoïdes avaient pénétré dans leur spermathèque.

Ces résultats s'expliquent partiellement par le niveau thermique à l'intérieur de la grappe d'abeilles. Tandis que 20-40 ouvrières ne pouvaient élever la température que de 2 a $3^{\circ} \mathrm{C}$ au-dessus de la température extérieure, 250 à 300 ouvrières l'augmentaient de 12 à $14{ }^{\circ} \mathrm{C}$ atteignant respectivement $32,7^{\circ} \mathrm{C}$ et $34,6{ }^{\circ} \mathrm{C}$. On a trouvé une très forte corrélation $(\mathrm{r}=0,94-0,99)$ entre le nombre d'ouvrières accompagnatrices, la température à l'intérieur de la petite grappe d'abeilles et le nombre de spermatozoïdes dans la spermathèque de la reine. Les coefficients de régression indiquaient qu'une augmentation de 100 ouvrières accompagnatrices augmentait la température dans la petite grappe d'abeilles de $3,5^{\circ} \mathrm{C}$ et le nombre de spermatozoïdes pénétrant dans la spermathèque de 629000 . 


\section{ZUSAMMENFASSUNG}

\section{EINFLUSS DER ZAHL DER PFLEGEBIENEN AUF DIE RESULTATE DER INSTRUMENTELLEN BESAMUNG VON BIENENKÖNIGINNEN, DIE BEI RAUMTEMPERATUR GEHALTEN WERDEN}

WOYKE (1979) konnte nachweisen, dass sich die Zahl der Spermien, welche die Spermatheka instrumentell besamter Königinnen erreichen, signifikant erhöht, wenn die Arbeiterinnen zu den Königinnen freien Zugang hatten. Wie Woyke u. JAsinski (1979) feststellten, waren bei Brutschrankhaltung $\left(34^{\circ} \mathrm{C}\right)$ zur Pflege einer besamten Königin 250 Arbeiterinnen nötig, aber viele Königinnenzüchter halten die Königinnen in Begattưngskästchen bei Freilandtemperaturen. Wie viele Arbeiterinnen sollten ausserhalb eines Brutschrankes zur Pflege der Königin vorhanden sein?

\section{MATERIAL UND METHODEN}

Es wurden insgesamt $60 \mathrm{Königinnen} \mathrm{mit} \mathrm{je} 8 \mu$ l Samen inseminiert. Sie wurden verschieden grossen Gruppen von Arbeiterinnen in kleinen Kästchen $5,5 \times 12 \times 12 \mathrm{~cm}$ zugesetzt und unter einem Schutzdach gehalten. Die Temperatur in der kleinen Traube wie die Aussentemperatur wurde zweimal täglich gemessen. Zwei Tage später wurden die Königinnen getötet und es wurde die Zahl der Spermatozoen in der Spermatheka gezählt.

\section{RESULTATE}

Königinnen, die nach der instrumentellen Besamung zusammen mit 20 Arbeiterinnen gehalten wurden, wiesen im Durchschnitt 1,825 Million Spermatozoen in der Spermatheka auf. Eine Vermehrung der Zahl der Pflegebienen führte zu einer höheren Zahl von Spermatozoen in der Spermatheka. Die grösste mittlere Zahl von 4,102 Millionen Spermatozoen wurden in der Spermatheka von Königinnen gefunden, die von 350 Pflegebienen umgeben waren. Diese Königinnen hatten 2,277 Millionen mehr Spermatozoen als diejenigen, die mit 20 Arbeiterinnen gehalten wurden; das bedeutet, dass in die Spermatheka von Königinnen, die mit der höchsten Zahl von Begleitbienen gehalten wurden, eine 2,25 fache Zahl von Spermatozoen eingewandert war.

Diese Resultate können z.T. durch das Temperaturniveau in der Bienentraube erklärt werden. Während 20-40 Arbeiterinnen die Temperatur nur um 2-3 ${ }^{\circ} \mathrm{C}$ über die Aussentemperatur erhöhen konnten, waren 250-350 Arbeiterinnen in der Lage, die Temperatur um $12-14^{\circ} \mathrm{C}$ zu erhöhen, wobei $32,7^{\circ} \mathrm{C}$, bzw. $34,6^{\circ} \mathrm{C}$ erreicht wurden. Eine sehr hohe Korrelation $(r=0,94-0,99)$ wurde festgestellt zwischen der Zahl der Pflegebienen, der Temperatur im Innern der kleinen Bienentraube und der Zahl der Spermatozoen in der Spermatheka der Bienenköniginnen. Regressionskoeffizienten zeigen, dass eine Zunahme der Pflegebienen um 100 die Temperatur in der kleinen Bienentraube um $3,5^{\circ} \mathrm{C}$ und die Zahl der Spermatozoen, die in die Spermatheka gelangen, um 629000 erhöht.

\section{REFERENCES}

MaCkensen O., 1969. - Effect of Diluents and Temperature on Instrumental Insemination of Queen Bees. J. Econ. Ent. 62 (6) : 1370-1372.

VESELY V., 1970. - Retention of Semen in the Lateral Oviducts of Artificially Inseminated Honeybee Queens (Apis mell. L.). Acta entom. bohemosl. 67 (2) : 82-92.

Woyke J., 1960. - Natural and Artificial Insemination of Queen Honeybees. Pszczeln. Zesz. Nauk. 4 (3-4) : 183-275. Also: Bee World 1962, 43 (1) : 21-25.

Woyke J., 1964. - Causes of Repeated Mating Flights by Queen Honeybees. J. apic. Res. 3 (1) : $17-23$.

Woyke J., 1979. - Effect of the Access of Worker Honeybees to the Queens on the Results of instrumental Insemination. J. apic. Res. 18 (2) : 136-143.

Woyke J., JASINSKi Z., 1973. - Influence of External Conditions on the number of Spermatozoa Entering the Spermatheca of Instrumentally Inseminated Honeybee Queens. J. apic. Res. 12 (3) : 145-151.

Woyke J., JAsinski Z., 1979. - Number of Worker Bees Necessary to Attend Instrumentally Inseminated Queens Kept in an Incubator. Apidologie. 10 (2) : 149-155. 